\title{
The future challenges facing South African human resource management
}

\author{
Karl B. Hofmeyr \& P. Johan Rall \\ Graduate School of Business Leadership, University of South Africa, P.0. Box 392, Pretoria, 0001 Republic of South Africa \\ Andrew J. Templer \\ Faculty of Business Administration, University of Windsor, Windsor, Canada
}

\author{
Received April 1995
}

\begin{abstract}
In this article we set out to examine how human resource professionals view the challenges facing South African companies. The views of a representative sample of human resource professionals were obtained to find out, in particular, what changes they expect in human resources management (HRM) in the future and what priorities need to be set for successful human resources management in a changing environment. In terms of human resource management objectives, respondents indicate that currently the emphasis in their work is on efficiency, human resource development, and industrial relations. They believe the major objectives should, however, emphasize human resource development and facilitating change, with considerably less of their time being committed to industrial relations issues. In terms of human resource activities, highest priority is given to managing organization change, affirmative action, and introducing participative management. Currently they are spending most of their time on industrial relations activities and training. Perhaps surprisingly, not much attention is being paid currently to the activities of cross-cultural management, and community upliftment and involvement. In the research we also investigate the balance of human resource responsibilities between HRM and line management. Activities which are perceived to be line management responsibilities are performance appraisal and employee communication. Those which should be a shared responsibility include employee development and affirmative action. Most respondents believe that the rate of progress with affirmative action is too slow. Perhaps predictably, human resource professionals see the most important challenge facing commerce and industry in the next five years to be the human resource challenge: in particular the need to improve productivity, affirmative action, training and development, and managing the demands of unions. The skills needed by human resource professionals to meet the challenges are sound 'business skills' as well as 'people skills'. They also need sound business knowledge and qualities of adaptability, empathy and sensitivity. In particular they need to be able to play a change agent role in their organizations.
\end{abstract}

In dié artikel ondersoek ons die siening wat professionele Suid-Afrikaanse menslike hulpbronbestuurders huldig ten opsigte van die uitdagings wat vir Suid-Afrikaanse maatskappye voorlê. Die sienings van 'n verteenwoordigende steekproef van professionele menslike hulpbronbestuurders is verkry rakende die veranderinge wat hulle voorsien in menslike hulpbronbestuur in die toekoms asook watter prioriteite daargestel moet word vir die suksesvolle bestuur daarvan in 'n veranderende omgewing. In terme van die doelstellings van menslike hulpbronbestuur, het respondente aangedui dat die huidige klem in hul werk val op doelmatigheid, menslike hulpbronontwikkeling en nywerheidsverhoudinge. Hulle is egter van mening dat die kerndoelstellings eerder menslike hulpbronontwikkeling behoort te wees en die fasilitering van verandering, met aansienlik minder tydsbesteding aan nywerheidsbetrekkinge-kwessies. Ten opsigte van menslikehulpbron- $k$ wessies word die hoogste prioriteit toegeken aan die bestuur van organisasieverandering, regstellende aksie en die bekendstelling van deelnemende bestuur. Tans word die meeste tyd bestee aan nywerheidsverhoudinge-aktiwiteite en opleiding. Verbasend genoeg word weinig tyd bestee aan die bestuur van kruiskulturele aktiwiteite en gemeenskapsbetrokkenheid en -opheffing. Die balans ten opsigte van die aanvaarding van verantwoordelikheid vir die bestuur van die menslike hulpbron, en of dit 'n lynbestuurs- en/of menslike hulpbronbestuursverantwoordelikheid is, word ook in die navorsing ondersoek. Prestasiebeoordeling en werknemerkommunikasie word gesien as lynbestuursverantwoordelikhede. Werknemerontwikkeling en regstellende aksie word geag as 'n aktiwiteit met gedeelde verantwoordelikheid. Die meeste respondente evalueer die tempo waarteen regstellende aksie vorder, as te stadig. Heel voorspelbaar, sien professionele menslike hulpbronbestuurslui, die belangrikste uitdaging waarvoor die ekonomie en die industrie in die volgende vyf jaar te staan sal kom, as dié van die menslike hulpbron. Die behoefte aan die verbetering van produktiwiteit, regstellende aksie, opleiding en ontwikkeling, en die bestuur van vakbondeise word uitgesonder. Die vaardighede wat menslike hulpbronbestuurslui benodig om hierdie uitdagings die hoof te kan bied, is gesonde besigheids- en interpersoonlike vaardighede. Verder benodig hulle ook besigheidskennis, die vermoë tot aanpasbaarheid, empatie en sensitiwiteit. Hulle moet in die besonder daartoe in staat wees om die rol van die veranderingsagent binne hul organisasies te kan speel.

*To whom correspondence should be sent.

\section{Introduction}

In this article we report on a mailed survey study of 205 human resource professionals who were asked for their views on the challenges facing South African human resource management (HRM) and the resulting changes that may be required. The results indicate considerable differences between perceptions of immediate and longer term priorities to be set in the performance of HRM. There is a concern that short-term efficiency may be accorded a priority which prevents due consideration being given to future development and societal issues. The survey also probes the roles of HR professionals and line managers, as well as the skills, knowledge, and qualities required by HR managers in the future.

\section{Problem definition}

In 1985, Walton wrote, 'Today we are in the midst of a pattern of profound change in the way we think about and manage human resources in business' (1985: 3). This change includes activities that have been given many names - quality of work life, employee involvement, socio-technical systems, innovative work structures, and participative management. The transformation that is occurring in HRM, however, is far broader than any of these names imply. Attention is shifting 
towards the management of change, the challenge of organizational effectiveness and the overriding cost concerns of tough economic times.

Lawler (1990) points out that HRM has been characterized by ongoing change for the past few decades. Into the mid 1980 s, traditional HR administration developed many centralized, single-purpose mechanisms for an entire company: for example, a centralized job evaluation-based approach to pay. The development, design, and administration of such systems was the responsibility of HRM. This centralized approach had significant limitations and has proved to be a poor fit in many contemporary business situations. Therefore, a shift from traditional to diverse and pro-active systems is evolving to enhance the difficult and demanding goal of organization effectiveness. These shifts affect and involve all members of the corporation in meeting their individual challenges of effectiveness and efficiency. All members of the organization must contribute for success to occur. Fulmer \& Graham agree with the need to manage change: 'the importance of corporate learning has becn further emphasize by fundamental changes in the business environment:

1. the pervasive use of high technology, including computers in the workplace;

2. the increasing complexity of competitive issues;

3. the slow growth in demand that resulted from the maturing of many markets and industries; and

4. the growing role of time as a competitive weapon and measure of excellence' (1993: 30-31).

The challenges resulting from the general change in HRM have been accentuated by additional South African issues such as the political transformation, and the many implications of the Reconstruction and Development Programme (RDP). This multi-faceted programme acknowledges the oppression and discrimination which resulted from apartheid and seeks to address the need for transformation and renewal in South African society. Amongst numerous other objectives, the RDP aims to provide access to modern and effective services such as electricity, water, telecommunications, transport, and health. Emphasis will be placed on human resource development, including an emphasis on education and training, life-long learning, and a sustained and structured approach to affirmative action. The RDP will provide a framework which will influence the priorities set by companies in areas ranging from the need to readdress structural problems in the economy, to job creation, to trying to foster a new and constructive relationship between people, their organizations, trade unions and Government. The challenges for human resources management are obvious. According to the White Paper on Reconstruction and Development:

'The Government's economic policies require human resource development on a massive scale. Improved training and education are fundamental to higher employment, the introduction of more advanced technologies, and reduced inequalities. Higher labour productivity will be the result of new attitudes towards work and especially new skills in the context of overall economic reconstruction and development. New and better management skills are urgently required' (1994: 21).
The question naturally arises, how are South African human resource managers responding to the challenges? In this article we report on a study which set out to answer this question.

A second reason why a study of this nature is important has to do with the notion of HRM effectiveness. Given the challenges mentioned above, HRM will be in the spotlight in the future. Not only will human resource managers be evaluated more rigorously in terms of the contribution they make to the business, but their endeavours probably will impact directly the success, even survival, of the enterprise. Horwitz (1991), for example, refers to the need for objective data showing the contribution of human resources (and industrial relations) to organizational effectiveness.

There are a number of reasons why HRM effectiveness is topical. As Templer \& Cattaneo (1991) point out, firstly, there is a renewed recognition of the fact that people make the difference between success and failure, secondly, wages and salaries are often an organization's largest controllable cost, and thirdly, in the light of the changes taking place in South Africa, HRM effectiveness in areas such as employment equity, empowerment, and removal of discrimination will be critically evaluated. Thus more attention will be paid to measuring and monitoring the effectiveness of the human resources function and increasingly it will be expected to add value in very specific ways. Part of this evaluation will depend on the fit between the environmental pressures and the priorities defined by the human resource professionals. If HRM is addressing issues which are not relevant in the mid 1990s and are focussing their attention on yesterday's priorities they will be found wanting. The study assists in defining the priorities by examining the perceptions of HR management regarding the areas where they should be focussing their attention in the future.

In summary, the primary purpose of the study was to examine how human resource professionals view the challenges facing South African HRM and the resulting changes that may be required. Of particular interest were their perceptions of the priorities to be set in the performance of HRM and their satisfaction with the changes that have taken place.

\section{Methodobgy}

A questionnaire based on that used by one of the authors in an earlier study (Templer, 1980) was selected as the primary data-gathering instrument. This questionnaire was expanded to include a number of issues relevant to the current practice of HRM in South Africa.

The study used the mailing list of the Institute of Personnel Management and a total of 887 questionnaires were mailed. A response of 205 useable surveys was obtained, representing $23.11 \%$ of the sample. This response was taken to indicate a reasonable interest in the research on the part of South African HR managers. The responses provide the basis of this article.

\section{Analysis of results}

\section{Background information}

The profile of the companies that responded was analysed by ownership and industry. Most of the respondents' companies are locally owned $(77 \%)$ and the balance are American 
owned (3\%), British/European companies (9\%), other foreign ownership (2\%) and 'other' $(9 \%)$. The majority of respondents are employed in the manufacturing industry $(37 \%)$ with the rest in mining $(13 \%)$, financial $(9 \%)$, service $(13 \%)$, government/public sector (3\%), and other (24\%).

Most of the respondents are male $(93 \%)$, between the ages of 31 and $50(70 \%)$ and university graduates (80\%).

\section{Human resource management objectives}

HRM objectives are a set of goals that a human resource function 'might seek to fulfil'. The questionnaire investigated the perceived importance of 'now' and 'should be' points of view. The time spent on meeting each objective was the criterion for the 'now'. The ideal importance of each objective was the 'should be'. Specifically, respondents were asked to rank the objectives in terms of:

a. The time actually spent on meeting each objective now

b. How important respondents feel each objective should be ideally.

The rank orders of importance are displayed in Table 1. The results suggest that respondents assign the highest priority to efficiency, people development and industrial-relations issues but overlook wider community ones. Generating efficiency by helping the organization to make better use of its resources and to achieve certain cost savings is the highest current concern, but respondents feel that ideally it should begin to receive less attention. This overriding present concern for efficiency is probably a reflection of the current economic pressures expressed in cost-cutting, re-engineering, and downsizing.

In the future, respondents feel that human resource development along with facilitating change should be accorded a higher priority than efficiency. It is likely that this perspective reflects the view that human resource development and managing change go hand-in-hand to make a corporation effec-

Table 1 Rank order of objectives in terms of importance

\begin{tabular}{|c|c|c|}
\hline $\begin{array}{l}\text { Objectives } \\
\text { ( } 1 \text { = most important, to } 9 \text { = least important })\end{array}$ & $\begin{array}{l}\text { Importance } \\
\text { 'now' }\end{array}$ & $\begin{array}{l}\text { Importance } \\
\text { 'should be' }\end{array}$ \\
\hline $\begin{array}{l}\text { Efrieiency: to help the organization become more } \\
\text { efficient in its use of resources and achieve certain } \\
\text { cost savings }\end{array}$ & 1 & 3 \\
\hline $\begin{array}{l}\text { Human resource development: to train and de- } \\
\text { velop the human resources needed by the organiza- } \\
\text { tion }\end{array}$ & 2 & 1 \\
\hline $\begin{array}{l}\text { Industrial relations: to build effective relations be- } \\
\text { tween organizations and unions }\end{array}$ & 3 & 6 \\
\hline $\begin{array}{l}\text { Facilitating change: to help the organization to re- } \\
\text { spond appropriately to change }\end{array}$ & 4 & 2 \\
\hline $\begin{array}{l}\text { Relationships: to create and maintain a co-operative } \\
\text { climate of relationships in the organization }\end{array}$ & 5 & 4 \\
\hline $\begin{array}{l}\text { Human resource supply: to obtain and motivate the } \\
\text { human resources needed by the organization }\end{array}$ & 6 & 7 \\
\hline $\begin{array}{l}\text { Conflict resolution: to prevent potential conflict by } \\
\text { building communication bridges between cultural } \\
\text { and racial groups }\end{array}$ & 7 & 5 \\
\hline $\begin{array}{l}\text { Responsibility: to meet the organization's legal and } \\
\text { governmental responsibilities }\end{array}$ & 8 & 9 \\
\hline $\begin{array}{l}\text { Community involvement: to assist the organization } \\
\text { in uplifting the community in which it operates }\end{array}$ & 9 & 8 \\
\hline
\end{tabular}

tive. Thus it is encouraging to see that HR professionals ar planning to have the resources in place to better handle the changing corporate needs in the future. The difference in the ranking given to industrial relations also is interesting Whereas currently it is ranked third in importance, the rant. ing in terms of importance as it 'should be' drops to 6. This suggests that there might be a shift away from industrial rela tions as one of the primary concerns of HRM in the future.

In both rankings, less importance was attached to more qualitative issues such as conflict resolution, ranked 7, and community involvement, which was ranked 9 in importance.

The low priority accorded to community involvement (ssisting the organization in uplifting the communities in which it operates) is a source of some concern. Community problems, in particular violence, unemployment, lack of housing, and the breakdown of education in some areas, will continue to impact industry, both in terms of investor confidence and the stress it places on many employees. The low ranking may suggest a managerial approach of trying to insulate the organization from community issues, to attend to internal problems of efficiency and productivity. Some acknowledgement of community involvement is found in the move from 9 to 8 of this objective in the ranking of priorities for the future. How ever, the low ranking remains a concern since external macro and internal micro issues are interlocked. Therefore, this under-weighting of broader community issues may result in future problems for HRM. There seems to be little doubt that such issues will become more important to organizations in the next few years.

\section{Progress towards objectives}

Respondents were asked to rate the progress that their human resource function had made towards achieving its most important current objective. From Table 2 it can be seen that general progress towards meeting the objectives is viewed as positive.

Respondents were also asked to state the methods now followed in meeting their 'most important' current priority. Respondents considered the most important mechanisms to be:

\section{Efficiency}

- Organizational renewal - the development of people to fit into new structures

- Ongoing research and development

- Effective selection/recruitment - having the right people in the right place at the right time

\section{Human resource development}

- Special training courses (in-house and external) as well as on-the-job training

Table 2 Progress towards objectives

\begin{tabular}{lc}
\hline Reached objective & $9.8 \%$ \\
Considerable progress & $65.5 \%$ \\
Little progress & $20.6 \%$ \\
No real progress & $4.1 \%$ \\
\hline
\end{tabular}


- Broad development - educational assistance, mentoring, literacy, succession planning

\section{Industrial relations}

- Sound relationship with union members, built on trust. Emphasis placed on conflict management

- Regular meetings - sharing goals, informing all, open and honest communication

\section{Facilitating change}

- HR function facilitating process of organizational change/ sensitizing management to change/being proactive

- Introducing a change programme - working groups, discussions, seminars, monitoring, making people aware of need for change

- Staying in continual touch with local and international business, political and HR leaders and focus on building a new future in a context of dynamic change, keeping abreast of business and political changes

\section{Human resource management activities}

In the next part of the survey, respondents were asked to rank order a list of $17 \mathrm{HRM}$ activities, again in terms of their actual importance 'now' and their ideal importance as they 'should be'. Results are summarized in Table 3.

The key activities in terms of current importance were found to be: industrial relations, training, organization change, and management development. These activities clearly relate to the key objectives highlighted earlier, namely efficiency, human resource development, industrial relations, and facilitating change.

In their response to the question: 'how important do you feel each activity should be ideally?', respondents indicated that there should be considerably more emphasis placed on

Table 3 Rank order of activities in terms of importance

\begin{tabular}{|c|c|c|}
\hline \multirow{2}{*}{$\begin{array}{l}\text { Activities } \\
\text { (l = most important, to } 18=\text { least important }\end{array}$} & \multicolumn{2}{|c|}{ Importance Importance } \\
\hline & 'now' & 'should be' \\
\hline Industrial relations & 1 & 7 \\
\hline Training & 2 & 4 \\
\hline Organization change & 3 & 1 \\
\hline Management development & 4 & 5 \\
\hline Introducing participative management & 5 & 3 \\
\hline Affirmative action/black advancement & 6 & 2 \\
\hline Human resource planning & 7 & 6 \\
\hline $\begin{array}{l}\text { Employment equity and the removal of discrimina- } \\
\text { tion }\end{array}$ & 8 & 8 \\
\hline Remuneration & 9 & 14 \\
\hline Recruitment and employment & 10 & 12 \\
\hline Performance appraisal and review & 11 & 11 \\
\hline Job evaluation and design & 12 & 15 \\
\hline Cross-cultural communication & 13 & 10 \\
\hline Human resource records and computer systems & 14 & 17 \\
\hline Cross-cultural management & 15 & 9 \\
\hline Health and safety & 16 & 16 \\
\hline Community upliftment and involvement & 17 & 13 \\
\hline
\end{tabular}

organization change and affirmative action and significantly less on industrial relations matters. This perspective may be a function of the transition taking place in the country with a consequent pressure on affirmative action, as well as the reduced attention given to industrial relations, as noted earlier.

It is likely that the changes taking place will, out of necessity, create a heavier reliance on participative solutions, such as employee empowerment. This is reflected by the importance attached to introducing participative management ranked 5 in importance now and moving to 3 in importance as it should be'.

Once again, community and cross-cultural issues are ranked low in priority (17 and 15 respectively). They are given somewhat higher priority in terms of their 'should be' importance, moving to 13 and 9 in the ranking. Affirmative action is also perceived to require considerably more attention, moving up from rank 6 (now) to rank 2 (should be). It is somewhat surprising, however, to see that 'employment equity and the removal of discrimination' is ranked midway down the list (8). Since this is inextricably linked to affirmative action, one would have expected it to have a higher ranking, at least on the 'should be' list. This could be a cause for concern if it suggests that affirmative action refers primarily to placing disadvantaged groups in supervisory and management positions rather than a broader strategy of creating a culture and climate free of discrimination. It may be that these low rankings indicate that equity concerns already have been addressed by HRM functions and can now be accorded a lower priority, but this is unlikely. Certainly other studies (Hofmeyr, 1994) show that strong perceptions of discrimination in the workplace still exist.

It could be argued that some of the activities are not mutually exclusive: for example, 'affirmative action' and 'employment equity and the removal of discrimination', or 'crosscultural communication' and 'cross-cultural management'. As in the case of the objectives (see Table 1) the researchers could have provided definitions but felt this would be cumbersome. Furthermore, where there may be some overlap between activities, these activities are ranked close to each other (6 and 8,13 and 15 in the examples given) which suggests that the absence of definitions did not significantly affect the overall outcome of the findings.

\section{Responsibility for human resource management activi- ties}

Participants were asked to specify the balance of human resource responsibilities, between $\mathrm{HRM}$ and line departments. In this study, we defined responsibility as overt action that must be taken to accomplish a task, an objective, or a plan. Within this perspective, identifying the balance of responsibilities is important, since it does not make sense to hold HRM accountable in areas where no responsibility exists. Results are presented in Figure 1.

Not surprisingly, there is a strong tendency towards the traditional view that HRM should be primarily responsible for administrative functions such as human resource planning and staffing, compensation and benefits planning and administration, employee support, and employee and union relations. Issues accorded a shared responsibility were organizational development and change, employee development 
and line management, but it appears that neither party is driving change in this area.

Third, efficiency is a top priority 'now' issue and may result in short-term cost savings. It is nonetheless dropping somewhat in priority. However, operational progress is a daily, ongoing challenge. Line managers must continue to work with HRM to reduce everyone's traditional administrative and industrial relations burden. Without common goals, each functional area will continue to act independently, at a time when shared responsibility is desperately needed.

Fourth, as noted above, the HRM professionals in this study do not emphasize the value of engaging in broad community areas, such as cross-cultural communication, the management of diversity and community involvement. However, business organizations will increasingly be expected to lead the way in solving these challenges. Thus, there is little choice for HRM but to increase their efforts to address these issues and plan for an increase in corporate responsibility and involvement.

Finally, we noted earlier that HRM is likely to be judged more critically in the future in terms of its effectiveness. More objective criteria will be applied to assess whether the HR function is adding value, particularly in the priority areas of the future. HRM which does not make the shift from the 'now' priorities to the 'should be' priorities identified in the research will be judged to be ineffective. Also it will miss the opportunity to make the contribution demanded of it at a time of transformation in the society. HRM finally can come of age if it meets the people challenges which many recognize as the priority area for the next decade in South Africa.
This research article presented the findings from medium and large companies, but may have implications which are just as applicable to small businesses. Solving these future challenges will not be easy and will require visionary managers who are the product of innovative management development programmes. This may provide the opportunity for useful partnerships between companies, educational institutions, communities and government.

\section{References}

Fulmer, Robert, M. \& Graham, Kenneth, R. 1993. 'A new era of management education', Journal of Management Development, Vol. 12, No. 3: 30-38.

Hofmeyr, K.B. 1994. 'What do South African managers think of affirmative action?', The Innes Labour Brief, Vol. 5. No. 4: 43-46.

Horwitz, F.M. 1991. 'Determinants of effectiveness in industrial relations', South African Journal of Labour Relations, Vol. 15, №. 1: 3-20.

Lawler, Edward, E. 1990. Strategic pay: aligning organizational strategies and pay systems. San Francisco: Jossey-Bass, Inc.

Templer, A.J. 1980. 'Personnel practice in South Africa: how British companies rate', Personnel Management, August: 28-31.

Templer, A.J. \& Hofmeyr, K.B. 1989. 'A national investigation of the correlation between perceptions of human resource management practices and organisational effectiveness', South African Journal of Business Management, Vol. 20, No. 1: 7-12.

Walton, Richard, E. 1985. 'HRM, trends and challenges', Harvard Business School. Harvard: Harvard Business School Press, 3$11 \mathrm{pp}$.

White Paper on Reconstruction and Development: Government's strategy for fundamental transformation. 1994. September. 